\title{
Securitization, alterity, and the state Human (in)security on an Amazonian frontier
}

\author{
Marc Brightman and Vanessa Grotti
}

\begin{abstract}
Focusing on the region surrounding the Maroni River, which forms the border between Suriname and French Guiana, we examine how relations between different state and non-state social groups are articulated in terms of security. The region is characterised by multiple "borders" and frontiers of various kinds, the state boundary having the features of an interface or contact zone. Several key collectivities meet in this border zone: native Amazonians, tribal Maroon peoples, migrant Brazilian gold prospectors, and metropolitan French state functionaries. We explore the relationships between these different sets of actors and describe how their mutual encounters center on discourses of human and state security, thus challenging the commonly held view of the region as a stateless zone and showing that the "human security" of citizens from the perspective of the state may compete with locally salient ideas or experiences of well-being.
\end{abstract}

Keywords: border, French Guiana, gold mining, healthcare, human security, indigenous and tribal peoples, securitization, Suriname

\section{Introduction}

The Maroni River marks the boundary between Suriname, to the west, and French Guiana, to the east. From its dark headwaters broken by treacherous rapids, to the wide stretch of muddy water that sedately flows between Albina and St. Laurent, the small towns near its mouth, it forms a peculiar international border in South America. French Guiana has the full status of a French overseas département, and Suriname, formally known as Dutch Guiana, obtained independence from the Netherlands in 1975. The Maroni therefore constitutes a border between a developing, postcolonial nation, and one of the European Union's nine UltraPeripheral Regions (Grenier, 2011, p. 17). Because of its rich and complex history and its extraordinary natural environment, this river is a thriving example of the border as "interface" rather than "margin" (Boudoux d'Hautefeuille, 2012), a place of intense movement and interaction. The 
river itself constitutes the main vector of movement along the border, even more than across it. Most importantly, as a social space, it is a "contact zone," fragmented with multiple environmental, social, and ontological borders, visible and invisible, where distinct collectivities "meet, clash, and grapple with each other, often in contexts of highly asymmetrical relations of power" (Pratt 1991, p. 34). ${ }^{1}$ It is useful to analyze these relations in terms of security, and specifically human security, because it helps to achieve critical clarity on central anthropological issues of social cohesion, agency, and power (Eriksen, 2010). In our analysis we will consider the effects of "security discourses" (Pedersen and Holbraad, 2013, p. 9), which sometimes have a tangential relationship to the agency of the state. These are discourses that appeal to uncertainty about the future and refer to threats, dangers, or fears (Pedersen and Holbraad, 2013, p. 2). They may enlist or implicitly refer to the idea of security familiar from international relations, but we are primarily interested in their local expressions, modalities, and effects. Our purpose is to study how encounters between radically different others are represented in terms of security: without necessarily sustaining an anthropological concept of security, we explore anthropologically the effects of discourses and ideas of security as used by different social actors. ${ }^{2}$

\section{State and securitization in a contact zone}

Despite the river's role as a regional hub of economic and cultural activity, and despite its arguably strategic position as a gateway to France and Europe, the state appears to be strangely absent on either side: border controls are minimal and ignored by most local inhabitants as well as migrants who travel from neighboring countries (Brazil, Guyana) and Caribbean islands, such as Saint Lucia and Haiti. The relative lack of state infrastructure in the Maroni basin has led some authors to describe it as a "government void," where historical conflicts have paradoxically generated the relatively "peaceful" cohabitation of distinct ethnic and national communities (Kruijt \& Hoogbergen, 2005, p. 199). We will argue, however, that behind this superficial absence, the state manifests itself through forms of coercion and political institutional control, first and foremost in discourses and practices of securitization that focus on specific collectivities, including the region's native tribal and indigenous inhabitants as well as the Brazilian migrants mostly involved in gold extraction. The French state in particular asserts its presence through the provision of healthcare and military operations. The Creole population being unable to furnish enough qualified personnel, the state is to a large extent represented by Metropolitan French employees who work for the most part on short-term contracts as civil servants in all 
sectors of the administration, notably as healthcare providers. We argue that these non-native collectivities share a detachment from the region and a temporality based on the short-term and the projection of a personal and social future away from the Maroni. This processual detachment leads to the construction of a discourse of securitization that alienates local inhabitants and promotes a state of insecurity, especially at the human level.

The detachment and impermanence of non-native collectivities in the region can be dated back to the early days of European New World exploration (Harris, 1928; Hemming, 1995; Hulme \& Whitehead, 1992). British, French, and Dutch colonizers remained ensconced along the Guianese coast where they traded with the Amerindian inhabitants and later, in Dutch Guiana, established plantations with slave labor in the seventeenth century (Price, 2011; Williamson, 1923). Fugitive African slaves from the sugar plantations found refuge in the forests of the Maroni region alongside the Central Carib and Arawak populations (Price, 2011, p. 10). Here, too, the few who escaped the notorious French penal colony at St. Laurent sought the safety of the forest. Over the centuries, relations between the new Maroon societies and the colonial powers unfolded through a series of wars and treaties, ${ }^{3}$ while Amerindians nurtured reciprocal ties with their tribal and European neighbors, based on cycles of warfare and alliances, which are far from forgotten. In peacetime, the Maroni river and its tributaries have always been the main thoroughfare, in the absence of roads, and the Maroons, especially the Aluku and Saramaka, have continued to dominate river transportation through their superior skill at passing the numerous dangerous rapids, which can be fatal to less expert pilots (Jolivet, 2007, p. 94). With this rich history of colonial and interethnic wars, the Maroni remains more than a state boundary: in relation to the state, it is a peculiar liminal zone populated by independent collectivities that have challenged colonial and postcolonial authorities.

This zone is characterized by a proliferation of borders. The first of these are what might be termed "ethnic" borders: those between local, non-state collectivities such as cultural, linguistic, and territorial groups. The history of the relationship between Amerindians and Maroons has included periods of peace and war, sometimes involving alliances with Europeans, starting with the Kali'na's role in Dutch expeditions to capture runaway slaves. Their most recent territorial conflict ended in the late nineteenth century with a peace treaty, sealed by the mutual consumption of the blood of the chiefs of the warring parties, which established precise territorial limits. ${ }^{4}$ These are generally respected, although they remain invisible to outsiders, and they are protected with life-threatening curses, which may be interpreted as placeholders for an implicit threat of violence. The most recent fighting between Maroons and Amerindians took 
place through their involvement on opposite sides in the Surinamese civil war in the 1980s (Dupuy, 2008, p. 190-195; Jolivet, 2005, p. 105). However, relations between these two collectivities are rapidly worsening due to the environmental and social pressures brought by the current gold rush on their ancestral land.

This gold rush has created an environmental frontier, another kind of border now pervading the Maroni basin. Since the early 1990s, thousands of Brazilian migrants, mostly from the northern states of Pará and Maranhão, have entered Suriname and French Guiana to work alongside smaller numbers of Maroons and Amerindians, cutting forest and scouring creeks and river beds for gold (Simonian \& Da Silva Ferreira, 2006; Theije, 2006; Theije \& Bal, 2010). This frontier, we suggest, exists for certain social groups and not for others: life in the forest is perceived by Europeans and Brazilians as an antagonistic struggle against the forces of nature, manifested through illness such as malaria and through other natural dangers such as snakebites, but for the native Amerindians and Maroons, the sharp distinction between nature and culture, taken for granted by Euro-American cosmologies, has little meaning (Descola, 2005). For them, something that might be termed an ontological border plays a more important role in daily life. The categories, expectations and norms that are taken for granted by one set of actors are not necessarily shared by others, and while this may be a feature common to other cosmopolitan settings or contact zones, it is particularly acute in a region in which quite radically different social groups live alongside each other, and where it is accompanied by some stark power differentials. On the Maroni, Amerindians and Maroons come to encounter the Metropolitan French who run the state-provided services on the French bank of the river. These last, including teachers, nurses, and state functionaries such as customs officials and even gendarmes, tend to work for one-off tours of duty, lasting three months, for which they are paid often several times the usual rate to compensate for what is perceived to be the parochial nature of their posting. It is in these encounters that, we argue, socialities of securitization are produced - that is to say, sets of social relations that are based on, and experienced in terms of, the friction (Tsing, 2005) between different parties' perceptions of security; socialities that are thus based on "working misunderstandings" or equivocal compatibilities (Piña Cabral, 1999; Sahlins, 1979).

\section{War, slavery, and human (in)security on the Maroni}

The Maroni basin has been marked by concerns for human security since at least the late seventeenth century. The first Maroons were from the first 
generation of slaves to be brought from Sub-Saharan Africa, and so had themselves been victims of forced migration (Price, 2011). Their escape from the brutal certitudes of slavery was a flight into the unknown, but the forest provided security from oppression and secure possession of their persons (to evoke Locke).

Indeed, at first sight, the freedom of the Maroons may be taken to exemplify the free individual at the heart of liberal theory, from which the concept of human security emerges (Eriksen, 2010; Pedersen and Holbraad, 2013). However, the societies they formed are far from individualistic, and Maroon people distinguish themselves from the bakaa, a category that broadly refers to "white people, and those who share their individualized way of life," that is, the other principally urban ethnicities of the region, such as Creoles, "Hindustanis," "Javanese," etc. (Jolivet, 2008, p. 93). One Ndjuka leader told us that he dislikes the term Maroon and prefers "Africans" - emphasizing even further his people's difference from the descendants of freed slaves known as Creoles. ${ }^{5}$ In this vein, the Maroni appears from a Maroon perspective as a place of refuge from state violence; contrary to Hobbes, the state, whose apparatus is dominated by bakaa, appears to pose a threat to human security and, indeed the collective security of Maroon clans (lo) and tribes, these themselves being the prime guarantors of the security of individual persons.

This view is underlined by the more recent history of the civil war of the 1980s in Suriname. After the rise to power of Desi Bouterse in 1982 following the 1980 military coup, relations with the interior "temporarily improved" as welfare provisions were ameliorated and development policies for the interior were seriously discussed (Kruijt \& Hoogbergen, 2005, p. 203). Administrative obstacles to Maroon participation in public life were removed, and one Ndjuka from the bauxite mining region of Cottica, Ronnie Brunswijk, quickly rose through the ranks of the army to become a member of Bouterse's private security guard. From 1984, a personal conflict between the two men spiraled into an armed confrontation between Bouterse's army and Brunswijk's own militia, the Jungle Commando (Jolivet, 2007, p. 95, 2008, pp. 92-93), which opposed Creoles and Maroons in a civil war that lasted until 1992. Brunswijk led guerrilla attacks against the state, taking effective control of eastern Suriname and raising funds through drug trafficking. Bouterse retaliated with "counterinsurgency operations": "Villages and settlements were plundered, burned down and flattened with bulldozers" (Kruijt \& Hoogbergen, 2005, p. 203), and the army bombed the island of Langatabbetje. As the fighting escalated, nearly 10,000 people (c. 8,500 Maroons and 1,500 Amerindians) fled to French Guiana. France registered them in 1991, giving them identity cards to allow them to circulate freely within a restricted part of the dépar- 
tement (Kruijt \& Hoogbergen, 2005, p. 203), but without granting them the status of refugees (French 1991). They were allowed to stay in makeshift camps, where the St. Laurent population perceived them as a nuisance, and at the end of the war the French military destroyed the camps, despite the continuing state of insecurity in many of the refugees' home villages in Suriname. Indeed, for this reason, many Ndjuka and Saramaka refugees refused the funds offered by the French state to encourage their return home (Jolivet, 2007, p. 95). Today, eastern Suriname is relatively peaceful, but a large number of Surinamese Maroons have remained in French Guiana, only some of whom have been granted French citizenship. The Surinamese state never resumed the initiatives for integration and development that were emerging in the early 1980s, although there have been sporadic interventions, as we shall see. The principal motor of development and change has instead been the informal economy, most notably that surrounding the gold rush that took root even as the civil war was drawing to a close at the beginning of the 1990s.

\section{Gold and insecure sociality}

Under economic pressure at home, thousands of poor migrants from northern Brazil flocked to Suriname from the 1990s onward to claim part of the riches that lay hidden under the forest and waterways of the Maroni region. These gold miners, known as garimpeiros ("prospectors" in Portuguese), choose to yield the benefits of what Eriksen calls "insecure sociality": their lives are dominated by hazards, risks to safety, and they have few sources of "security" of any kind: in the absence of physical security they have little access to healthcare, and their material security fluctuates radically from wealth to penury $(2010, \mathrm{p} .11)$. The perpetual threat of violence is such that they must rely on little more than the weapons they carry for the security of their person (Kruijt \& Hoogbergen, 2005), for they do not benefit from the strong group solidarity that characterizes the kinship-based societies of the Maroons and Amerindians (Theije \& Bal, 2010). Yet, the garimpeiros may experience this short-term insecurity in their everyday lives as a form of freedom of agency, and as the price to pay for an imagined future time of financial security, when they will have the gold, or the money, to set up their own small businesses at home in Brazil; indeed some garimpeiros send money home to their families for this purpose (Theije \& Bal, 2010). As Pedersen and Holbraad have argued (2013), security has a particular relationship with time, and any idea of security is based upon imagined future scenarios. (In)security thus depends upon historically, socially, and culturally defined temporalities. 
In this case, (in)security is also divided between places, as the risks that garimpeiros live with in the present on the Maroni are the price to pay for a stable family home in Brazil as well as a secure future for themselves when they return.

It is not only Brazilians who mine for gold. Many Maroons and Amerindians are also involved in a number of ways, and during our own field research among the Trio of the upper Tapanahoni, a major tributary of the Maroni, and among the Wayana of the Litani (the headwaters of the Maroni itself), we met several men who had worked as miners. These young men exposed themselves to the considerable dangers of this work, despite having opportunities that their Brazilian counterparts lacked. They already had the possibility of cutting swidden fields and building houses in their home villages or those of their wives, and some of them had indeed returned for the end of the dry season to cut and burn new swiddens and enjoy the seasonal dancing and feasting. Seeking gold merely gave them the chance to gain additional cash wealth, which they used to purchase small luxuries such as jewelry and electrical goods. Most of their earnings, however, were spent on transportation - in the absence of roads, travel to Amerindian villages is expensive, whether by air or by river, because of the fuel required. These men were as proud of their ability to speak Portuguese and of the words, including Portuguese nicknames, that they had tattooed on their bodies in the gold mining centers, as they were of any gold they had found or money they had made. When they returned to their villages for annual festivities they did so with the swagger of mythical heroes who had traveled to distant lands to fight monsters. Among the Trio and Wayana, as among other Amerindian peoples of lowland South America, personhood and indeed social identity and cohesion are paradoxically dependent on an engagement with alterity, which involves its consumption and appropriation into native symbolic structures. Older Trio and Wayana men who have worked as gold miners in the past rarely live differently from their contemporaries, but their scars, tattoos, and stories stand as evidence of their past exploits. Eriksen compares the sociality of insecurity with Ibsen's Peer Gynt, whose adventures brought him intermittent wealth and experience, but whose personality was like an onion: peeling away the layers of experience, he found no core (2010, p. 9). But Amerindian personhood, if it is constructed through youthful and heroic encounters with alterity, later solidifies into something more substantial through the daily round of commensality, compounding affective and consanguineal ties of kinship (Grotti, 2013, pp. 24-25).

However, if kinship and the routines of subsistence and daily and seasonal ritual provide a source of human security, these things are threatened even in remote villages by the encroaching presence of gold mining 
and the insecure sociality that surrounds it. Individualistic violence is intensified by cocaine and other drugs. Prostitution, although mostly involving the Brazilian women who are far less numerous than their male counterparts (Antonius-Smits, Altenberg, Binrleson, \& Taitt-Codrington, 1999; Kruijt \& Hoogbergen, 2005, p. 206), also sometimes involves Amerindian women, leading to fears of sexually transmitted diseases. ${ }^{6}$ Environmental pollution is an increasing threat, especially through mercury poisoning: mercury becomes especially concentrated in the large carnivorous fish that the Wayana favor in their diet, and has potentially serious consequences for unborn children (Charlet \& Boudou, 2005, p. 73).

\section{Risk and securitization in healthcare encounters}

According to the United Nations Trust Fund for Human Security, human health is one of the key domains from which the multi-dimensional analysis provided by a human security approach can benefit. From the organization's perspective, this means that addressing the environmental, economic, and social components of ill-health contributes to human security; the examples of obstacles to achieving good health come under generic goals, such as the improvement of health-care systems, the education of the public, or the development of local-level health insurance schemes that reach the most vulnerable people (UNOCHA, n.d.). In this light, the Maroni basin represents a challenge in itself to such consensual objectives: this border area is located at the interface between two national healthcare systems that do not have a poor health record in general terms; indeed, Suriname's healthcare compares reasonably favorably to other South American countries, and France has one of the best healthcare systems and health indicators in the world (PAHO/WHO 2012). Moreover, in French Guiana, since 2000, when a Universal Health Insurance (Couverture Médicale Universelle) was introduced, non-nationals, whether legally present on the territory or not (known as sans-papiers) can claim access to medical care and have their medical expenses reimbursed (Carde, 2012, p. 3).

France was nevertheless reprimanded recently by a UN human rights body about a "discriminatory political discourse" associated with "the increasing difficulties faced by certain inhabitants of [French] overseas territories in accessing health care without discrimination" (UNHCHR, 2010; Jolivet, Lebas, \& Chauvin, 2010, p. 1827). In a context of apparent general prosperity, healthcare provision in the Maroni basin (like the rest of French Guiana) is underperforming. Most services are concentrated in the hospital of St. Laurent, and the Maroon and Amerindian populations (not to mention garimpeiros) do not therefore have easy access to them. This 
is not only due to the legacy of the civil war that has left the Surinamese bank with little infrastructure, but also because of human and structural problems on the French side of the river (Jolivet et al., 2011; Weisberg, 2013).

Access to healthcare is also subject to bureaucratic obstacles, and attempts to address these have created further problems. The introduction of a universal healthcare plan has made healthcare providers living in French Guiana (who are either Creoles or Metropolitan French) feel responsible for controlling what they perceive to be an increasing influx of undocumented healthcare and welfare claimants. Local tribal and indigenous patients who live on either side of the Maroni often lack identity papers and entitlements to French social security, and this applies to more recent migrants to the region such as Surinamese or Brazilian nationals. As Carde suggests, healthcare professionals start to become discretionary regulators of immigration in their daily encounters with undocumented claimants (2012, p. 5).

The Maroni basin, with its history of conflict and migrations, has become a place where medical encounters are marked by the tension between caring and controlling. It can be argued that delivering health on this frontier zone becomes less about promoting individual human security than attempting to securitize a social space perceived as being in constant flux, and which the healthcare practitioners struggle to understand and identify with (Carde, 2010, 2012). Although previous studies have demonstrated that migration in the region is not driven by health-related motivations but rather by economic ones (Jolivet et al., 2011), healthcare professionals in French Guiana clearly seem to perceive the patients they deal with as radical others whose behavior is unpredictable and irrational: they consequently do not trust them to take their medicine or report changes in their condition. Their encounters, in theory marked by the sole concern of human security, tend in fact to be characterized by a lack of mutual understanding, which leads to an overuse of languages of securitization among the biomedical healthcare personnel. This takes place most notably in the field of maternal health: indigenous and tribal expectant mothers are pressurized to come to the hospital, often months before they are due to give birth, through deliberately emotive warnings that staying in their villages puts them and their babies at risk. As one healthcare practitioner in St. Laurent told us, antenatal care visits are just about one thing: scaring the woman patient so much about the potential risks to her child and the possibility of death that she feels compelled to travel all the way to the hospital to give birth. Many women, faced with the prospect of being separated from their families, often for many weeks, choose not to travel to the hospital, or wait until the last moment, when it may be too late. 
In French Guiana, as in the rest of France, there are no traditional birth attendants, no non-governmental clinics or dispensaries, no locally trained midwives or physicians. There are only private-practice and state-employed midwives and physicians, all trained in Metropolitan France (Weisberg, 2013, 26). All births are hospital-based, and in the case of the populations of the Maroni, are expected to take place either at the maternity ward of the Centre Hospitalier de l'Ouest Guyanais in St. Laurent du Maroni (lower Maroni inhabitants), or in the maternity ward of the Centre Hospitalier Andrée Rosemon in Cayenne (upper Maroni inhabitants). There are also two smaller privately-run maternity wards in Cayenne and Kourou. Since 2006, the regional health authorities have made it explicitly forbidden for women to give birth informally in the health centers (Centre de Santé) on the French bank on the Maroni river, especially in the largest post on the river located in Maripasoula. On the Surinamese bank, although women patients residing in the interior can give birth in the health posts of the Medical Mission Suriname or indeed at home, there has been a drop in recorded births in the past 10 years.

The French hospital in St. Laurent, which has one of the two free, statefunded maternity wards of the département, ostensibly provides a form of security against the threats posed to human health by disease and pollution but also by potential complications in biological processes, particularly pregnancy and childbirth. The very high rate of childbirth in this region makes this especially significant. Risks to health are perceived differently by medical professionals and patients in most contexts. Medical staff, often in place for too short a period to become familiar with local people, frequently focus on what they perceive as "risky" behavior on the part of patients, casting responsibility on them for any potential health problems that may arise while they are out of the direct control of the hospital. Relations between medical staff and patients are also caught up in anxieties and perceptions of questions of citizenship, as the former tend to assume that expectant mothers who wish to give birth on French soil do so in a bid to obtain French citizenship for their children, and thus to obtain for them the privileges of social security and better opportunities for employment.

Medical staff express fears of losing control over patients unaccustomed to the rigors of medical bureaucracy, and fears of exploitation of the system on the part of patients (Weisberg, 2003). This leads them to produce a discourse of securitization: their claims that the patients' health and the integrity of the state are felt to be at risk lead them to treat patients in an alienating manner, making patients less willing to place themselves in the hands of medical staff. Garimpeiros, for example, consequently turn to Surinamese health providers when they need healthcare. In a surprising reversal of the fears of French metropolitans and Creoles, Surinamese 
health officials blame the French authorities for what they perceive as migration towards Suriname to access healthcare there.

\section{State security vs. human security}

The role of the state in the provision of healthcare and the equivocations discussed above raise questions about the relationship between state interventions and human security. A more extreme, though less quotidian, example of state intervention in the Maroni region is that of the military operations that take place intermittently to remove unlawful mining operations. Many such operations have taken place in French Guiana since 2002, under a succession of codenames (such as Anaconda, Toucan, or Harpie) that reflect an escalating securitization discourse on the part of the departmental authorities. When French President Nicolas Sarkozy visited French Guiana in 2010, he declared that Operation Harpie should remain "permanent and perennial". Although controlling gold mining is primarily a matter for the police, the different administrative sectors, including the army, gendarmerie, police, customs, judiciary and several others, must coordinate to enforce a series of security objectives. ${ }^{7}$ In the same document, a report for the French Senate, the authors also note that, because of the "porosity" of the borders and because they share the same problems, neighboring states (i.e., Brazil and Suriname) need to be involved (Rohan, Dupont, Berthou, \& Antoinette, 2011).

While the nature and extent of this international cooperation are difficult to ascertain, a comparison of the French security operations of 2011 and 2012 can give an idea of their intensity, and the tone of the press reports suggests a public discourse of securitization beyond that of the state administration itself. While the government defense website headline reads "No end of year truce for Operation Harpie" (Ministère de la Défense, 2013), the newspaper France Guyane reports:

The numbers speak for themselves: $8.1 \mathrm{~kg}$ of gold seized last year compared to 11.7 in 2011. Nobody can claim these are good results. The same for the seizures of mercury ( $76 \mathrm{~kg}$ compared to $135 \mathrm{~kg}$ in 2011), firearms, etc. ...

The reality is that the press release presented to journalists yesterday morning at the Préfecture was pretty thin.... The number of operations? Reduced. It went down from 4,483 in 2011 to 3,789 last year. "In 2012, there were fewer missions than in 2011. The hunt for Manoelzinho is the explanation," underlined the Prefect Denis Labbé. Colonel Didier Laumont added that these missions to find the killer of French soldiers had made it possible to "asphyxiate the sites. We blocked the entire phenomenon during the whole Manoelzinho period. But we abandoned the coastal strip (in personnel)." Why was the hold not maintained then? 
"We couldn't maintain this pressure without risking seeing criminality

increase on the coast." (Roselé, 2013, our translation)

The usual number of personnel involved in Operation Harpie is 350 to 400 , and it seems that these carry out, on average, over ten operations a day. This report shows that, during the hunt for the garimpeiro Manoelzinho, who had killed French soldiers, the number of Harpie operations decreased slightly, as did the amount of gold seized, but according to this report, the increase in personnel, brought in from the coast, allowed a tight enough grip on the region for gold mining operations to be eliminated entirely.

No doubt the Operation Harpie and the hunt for Manoelzinho appear very differently from the point of view of other actors. But in this light it is difficult to view the Maroni region, at least on the French bank, as a "state void," as Kruijt and Hoogbergen call it (2005). While their argument is avowedly based primarily on Surinamese data, recent events appear to suggest that its validity may be becoming limited even for the Surinamese side of the river. In August 2008, Suriname launched Operation Clean Sweep. "Eighty police men and military were launched into Benzdorp [the most important gold mining centre, populated mainly by Brazilians] with the goal to 'order the interior' by 'bringing an end to all illegal activities...such as weapons, drugs and gold digging'" (Theije and Heemskerk, 2010, p. 361). An Aluku spokesman told the press that the Aluku gold miners were "shocked by the fact that local communities were not consulted about the operation beforehand" (Theije and Heemskerk, 2010, p. 361). Suriname thus seems to have begun to emulate the French approach to security in the Maroni basin, although the strategy here seems to be more one of intimidation rather than of attempting to make gold mining economically non-viable, as Anaconda was originally conceived to do. Moreover, there has been a simultaneous militarization of healthcare on the gold mining frontier in Suriname, ${ }^{8}$ which has been highly effective in reducing malaria; one consequence of this, however, is that a "natural" deterrent to gold mining has been removed, and anecdotal evidence suggests that it is leading to a further influx of garimpeiros.

De Theije and Heemskerk describe how the French gendarmerie secured and destroyed a gold mining raft in 2007 on the Litani River, a tributary of the Maroni in the disputed boundary zone between French Guiana and Suriname. This raft was the property of the Wayana village of Kawemhakan. They contrast the perception of the incident in French Guiana, where it was "merely seen in the context of a regulatory policy," and in Suriname, where it was "perceived as the destruction of the traditional form of livelihood of innocent native peoples," as well as an illegal French action on what is considered Surinamese territory (2010, p. 353), although 
they do not specify precisely which actors perceived things in this way. The authors rightly show that "indigenous and tribal peoples are not passively suffering from the gold rush," but are "active agents in steering gold mining developments in their homelands" (p. 354). In our own experience, the Trio and Wayana village of Tëpu on the upper Maroni had gone through at least two periods of acceptance and rejection of mining on its territory, as two successive headmen had allowed garimpeiros to work there, in return for payment, until they gave in to pressure from villagers to withdraw permission and expel the miners. Theije and Heemskerk identify a general shift in Wayana opinion, from a toleration of moderate mining activity on their territory in return for a share of the profit, to a rejection of mining as the gold rush intensified and more and more garimpeiros invade Wayana land, and the environmental and social problems begin to increase. This may not represent a simple, general shift. As these authors note, "different Wayana have different interests" (p. 354), some being in favor of gold mining and others rejecting it. But it seems that these different interests follow a pattern: in the case of Tëpu, the changes in attitude to gold mining hinged on the power relations between the chief and the people, as the payments were not evenly distributed and only a few Trio profited from the arrangement, whereas the presence of miners was associated with the introduction of strong alcohol, drugs, and violence, with which ordinary villagers grew increasingly dissatisfied.

\section{Land rights and the discourse of global environmental security}

The practice of mining on the Surinamese banks of the Maroni is linked in numerous and complex ways to questions of land rights. In technical violation of the Surinamese Mining Law, many owners of mining concessions delegate their exploitation to small-scale miners for a fixed fee or monthly percentage of production (Theije \& Heemskerk, 2010, p. 357). The national concession system conflicts with the customary land rights of indigenous and tribal peoples, whose leaders claim the right to control and profit over mining on their territory. Despite the Mineral Ordinance of 1932 (Kambel \& MacKay, 1999) and the Forestry Law of 1992 stipulating that customary rights of tribal communities should be taken into account, it provides no "measures for the protection of these rights," and does not "define procedures for consultation, compensation and appeal" (Theije \& Heemskerk, 2010, p. 357). In an overview of the legal framework in Suriname regarding the exploitation of natural resources, Kambel and MacKay conclude that there is no mechanism to incorporate indigenous and Maroon participation in decision making about resource exploita- 
tion, the country remains "without any form of environmental legislation, framework or otherwise," and there is inadequate protection in the forestry and mining laws (Kambel \& MacKay, 1999, p. 116). Meanwhile, according to law, French territory is "indivisible," meaning that "tribal peoples cannot obtain rights to a part of the territories based on ethnicity" (Theije \& Heemskerk, 2010, p. 357; cf. Martres and Larrieu, 1993), but in practice the state grants right of use to specific groups, although these are not officially based on ethnicity. In the Parc Amazonien de Guyane, created in 2007, which covers most of the southern part of French Guiana, there are precise rules designating areas for traditional use, including areas of right of use, as well as zones of libre adhésion (free adhesion) in which traditional activities such as hunting and collecting forest products are permitted, representing 1.4 million hectares of the park's total area of 3.4 million hectares (Parc, 2013).

There are numerous factors affecting the acceptance or rejection of gold mining on Amerindian territory. Certain village leaders can effectively accept or reject mining on their territory because of the lower level of pressure from miners and the strength of their perceived capacity to enforce their rejection of them. But elsewhere, where mining is more intense, leadership is more strongly contested and villages are smaller, village leaders have greater difficulty in exercising control and demanding substantial rents or shares of profit, because the state does not promise to act to enforce customary land rights. And, in other cases, particularly in Ndjuka territory, the Surinamese government itself infringes customary land rights by granting concessions to small entrepreneurs and large mining corporations. In contrast to Maroons and Amerindians, garimpeiros have no basis for claiming land rights, but they compensate for this with a flexible attitude, and unlike some Maroons, they do not worry about what will happen when the gold runs out (Theije \& Bal, 2010).

If concern over the destructive effects of gold mining provided part of the impetus for the creation of the Parc Amazonien de Guyane, similar concerns, combined with the threat to livelihoods posed by the state's granting of concessions to international corporations, led in recent years to the increasingly effective mobilization of Maroon peoples in defense of their customary rights. This began when some 6,000 Saramaka and Ndjuka were displaced from their land in from 1963 to 1964 to make way for a hydroelectric dam and reservoir in Brokopondo. As Kambel and MacKay write, "they were paid the equivalent of US3\$ in compensation and were not provided with secure land rights in their new areas" (1999, p. 105). Spurred by the state supported invasion of their lands by Chinese loggers in the 1990s, the Saramaka people finally took the case to the Inter-American Court of Human Rights, which ruled in their favor: 
[It ordered the] delimitation, demarcation, and granting of collective title over the territory of the Saramaka people; the granting to the Saramaka people legal recognition as having a collective juridical capacity [a legal personality]; removing or amending the legal provisions that impede protection of the Saramakas' collective property; adopting legislative, administrative, and other measures to ensure the right of the Saramaka people to be effectively consulted, and to give or withhold their free, informed, and prior consent with regard to development projects that may affect their territory. (Price, 2012)

Although Suriname has complied with none of the court orders, the ruling did lead the government to hold a conference on gold mining with the Maroons, in March 2011. On this occasion, the Maroon groups announced that they would tolerate no more concessions on their lands until the government recognized their land rights. This brought them into line with the Surinamese Amerindian organizations, and the government promised a conference with both indigenous and tribal peoples on land rights in June of the same year. At the same time, the government had decided to fall into step with the growing current in international development and conservation to merge these interests through a focus on "natural capital," and to seek development funding through REDD+, an emerging UN program of forest governance to fund forest conservation based on the economic value of emissions reductions (Brightman, 2014). Informed by the international indigenous peoples' movement, the indigenous and tribal organisations see REDD+ as a potential territorial threat through rent seeking: it may provide an incentive to outside parties to seek to purchase forests as their value as carbon sinks grows.

The land rights conference of 2011 was abruptly terminated by the Surinamese president, who seems to have been offended by the forthright tone of the demands of the Amerindian representatives, and the political debate continues. The events so far highlight the divergent perspectives of the state and the forest peoples, but at the same time, the historic convergence of indigenous and tribal positions. Indeed, as the state attempts to close its grip upon the interior, most recently in the name of environmental security, the common ground between Amerindian and Maroon parties becomes more evident. In relation to both gold mining and forestry, land rights have become the focus of bids for collective security among the various parties involved.

\section{Conclusion}

Rather than using the policy objectives of the "human security approach" as it is defined by the United Nations as an analytical framework, we have 
explored how the idea of "security," without clear definition, is employed in discourses that articulate the relationships between individuals and institutions, and between different non-state collectivities or social categories. We have used the idea of "securitization" to highlight that both human security and state security are enlisted in discourses that serve particular sets of interests. The idea of human security is based on an idea of the free individual actor, which has a specific history and emerges from liberal political theory. We do not contest its utility as a tool for promoting improved well-being, but we do suggest that its application may raise unforeseen problems unless one is aware of its limitations.

We have chosen to try to describe the relationships between different groups of actors, across multiple fault lines of difference (cultural, linguistic, economic, geographic), in a fragmented zone of multiple borders. This is important because it reveals how uncertainty about the future, fear, and perceptions of threat or danger, are colored by ontological difference and power relations, especially vexed in this postcolonial context on the peripheries of Europe and the Caribbean and Amazon regions. The universalist idea of security, whether applied to individual persons, small scale social groupings or the state, is necessarily and implicitly contested, very often by competing interests which can themselves be construed in terms of the 'security' of other actors. By comparing different perspectives, the difficulties of setting out a universal agenda for human security are made more visible.

For instance, the human security of citizens from the perspective of the state may compete with their human security in terms of locally salient ideas or experiences of well-being, and this is illustrated by our analysis of state interventions in the name of human health, territorial integrity and environmental security. Frictions between such perspectives may further contribute to the emergence of socialities of securitization, in which security discourses are enlisted to favor particular perspectives over others. A security approach carries its own threats and dangers. Security is difficult to measure; referring necessarily to uncertainty about the future, it is open to exploitation by the powerful, and it is for this reason that security discourses can be used to suspend the normal rules of conduct for states (Agamben, 2005; Schmitt, 2007). Such suspensions of normal rules of conduct may take place on a national level to justify acts of war, but they may also take place on a micro level, to justify the control of populations (Feldman and Ticktin, 2010). An agenda for a human security approach must therefore be to explore the ways in which the perspectives, interests, and needs of different individual and collective actors differ and, if possible, to identify their points of convergence. 


\section{ACKNOWLEDGMENTS}

This article was first presented at the Label conference "Human and environmental security in cross-border regions" at the University of Luxembourg in October 2013. We are grateful to the organizers, Harlan Koff and Carmen Maganda, to the conference participants, and to the anonymous reviewers for their comments and suggestions. The data presented in this paper was collected through field research funded by the following bodies: the UK ESRC, the Gates Cambridge Trust, Trinity College Cambridge, the Smuts Memorial Fund, the British Academy, the FP7 Marie Curie Actions Programme, and the John Fell Fund. Research in Suriname and French Guiana would not have been possible without the hospitality and kindness of our indigenous and non-indigenous friends, hosts and interlocutors.

VANESSA GROTTI is Wellcome fellow at the Wellcome Unit for the History of Medicine, Oxford University and Research Fellow at Wolfson College. She completed her PhD in Social Anthropology at the University of Cambridge in 2007. She has held posts at the Laboratoire d'Anthropologie Sociale (Collège de FranceEHESS), the London School of Hygiene, and Tropical Medicine and Oxford University. She has been working with Central Carib populations in Suriname, French Guiana, and Brazil for over a decade and has published on public health, medical anthropology, religion, kinship, and change.

MARC BRIGHTMAN is lecturer in social and environmental sustainability in the department of anthropology at University College, London. He completed his PhD at the University of Cambridge in 2007, and has held posts at the Musée du Quai Branly in Paris, Oxford Brookes University, the University of Oxford and the Graduate Institute in Geneva. His monograph, The Imbalance of Power: Leadership, Masculinity and Wealth in the Amazon, is due to be published by Berghahn.

\section{NOTES}

1. For further theoretical discussion of borderlands, see Green 2011, 2013; Wesley Scott 2012; Wilson \& Donnan 2012.

2. This article is based on the analysis of qualitative data collected by the authors during several periods of field research from 2003 onward; this included longterm (21 months) intensive field research in Suriname and French Guiana in both remote rural and urban settings. Field sites included villages, health centres, hospitals, and governmental and non-governmental headquarters. Informants were indigenous peoples (Trio, Wayana, and Akuriyo), Maroons (Njuka and Saramaka), government ministers, governmental and non-governmental officials, health practitioners, and policy-makers. Methods used included participant and non-participant observation, semi-structured interviews, and archival research. 
3. For further information on these treaties, see for instance Collomb \& Jolivet, 2008, and Kambel \& MacKay, 1999.

4. For a detailed discussion of Amerindian-Maroon relationship, see Dupuy, 2008. For further discussion of histories of identity formation in the region, see Aleman and Whitehead, 2009.

5. Maroons refer to themselves collectively as busikondesama (the people of the big forest villages) or, now more commonly, bosinenge (from "bush negro") (Jolivet, 2007, p. 98). For detailed accounts of the formation of tribal societies who escaped enslavement and the plantations, see Jolivet, 2007, 2008; Price, 2011; Thoden van Velzen and Hoogbergen, 2011; van Wetering \& Thoden van Velzen, 2013.

6. The rate of HIV infection in the Surinamese interior at the turn of the millenium has been estimated as high as $20 \%$ by Price in a critical review of demographic data on Maroon societies (2002, p. 83). Recent figures are difficult to obtain for the interior, but there is a dramatic contrast with the recent PAHO estimate, based on 2009 data, of 1.1\% for the country as a whole (PAHO 2012).

7. The report produced for the French Senate's Commission of foreign affairs and defense lists these as follows: 1) to identify, paralyze and dismantle the logistical flow of supplies (to illegal gold mining operations); 2) To identify the individuals involved (traders/organisers, canoe pilots providing transport, people smugglers, 'lookouts', etc. ...); 3) To indict the perpetrators of crimes and offences; 4) To conduct foreigners in an irregular situation (ESI) to the border; 5) to destroy, following the authorisation of the Public Prosecutor, the material used for the extraction of gold or providing logistical supplies to the clandestine sites; 6) To restore the sites (Rohan et al., 2011).

8. It emerged from some of our interviews that the Surinamese army had taken responsibility for establishing malaria treatment centers near gold mining camps in the interior.

\section{REFERENCES}

Agamben, G. (2005). Homo sacer: Il potere sovrano e la nuda vita. Turin: Einaudi.

Aleman, S., \& Whitehead, N. (Eds.). (2009). Anthropologies of Guayana. Tucson: Arizona University Press.

Antonius-Smits, C., Altenberg, J., Binrleson, T. \& Taitt-Codrington, T. (1999). Gold and commercial sex: Exploring the link between small scale gold mining and commercial sex in the rainforest of Suriname. In K. Kempadoo (Ed.), Sun, sex and gold: Tourism and sex work in the Caribbean (pp. 62-85). Landham: Rowman \& Littlefield.

Boudoux d'Hautefeuille, M. (2012). Entre marge et interface: recompositions territoriales à la frontière franco-brésilienne (Guyane/Amapá). Unpublished doctoral dissertation, Université des Antilles et de la Guyane.

Brightman, M. (2014). Audit sauvage: régimes de valeur de la terre et de la biodiversité en Amazonie. Ethnographiques, 27, - Biodiversité(S). Retrieved from http://www.ethnographiques.org/2013/Brightman 
Carde, E. (2010). Quand le dominant vient d'ailleurs et l'étranger d'ici: l'accès aux soins en Guyane au prisme de la double-altérité. Autrepart, 3(55), 89-105.

Carde, E. (2012). Immigration(s) et accès aux soins en Guyane. Anthropologie et Santé, 5. Retrieved from http://anthropologiesante.revues.org/1003.

Charlet, L., \& Boudou, A. (2005). Cet or qui file un mauvais mercure. In P. Menget, \& J.-P. Razon (Eds.), Guyane: le renouveau Amérindien. Special issue of Ethnies, 18(31-2), 72-81.

Collomb, G., \& Jolivet, M.-J. (Eds.). (2008). Histoires, identités et logiques ethniques: Amérindiens, créoles et noirs marrons en Guyane. Paris: Éditions du comité des travaux historiques et scientifiques.

Descola, P. (2005). Par-delà nature et culture. Paris: Gallimard.

Dupuy, F. (2008). Wayana et Aluku: Les jeux de l'altérité dans le Haut-Maroni. In G. Collomb, \& M.-J. Jolivet (Eds.), Histoires, identités et logiques ethniques: Amérindiens, créoles et noirs marrons en Guyane (pp. 165-201). Paris: Éditions du comité des travaux historiques et scientifiques.

Eriksen, T. H. (2010). Human security and social anthropology. In T. H. Eriksen, E. Bal, \& O. Salemink (Eds.), A world of insecurity: Anthropological perspectives on human security (pp. 1-19). London: Pluto Press.

Feldman, I., \& Ticktin, M. (Eds.) (2010). In the name of humanity: The government of threat and care. Durham: Duke.

Ferguson, B., \& Whitehead, N. (Eds.) (2000). War in the tribal zone: Expanding states and indigenous warfare. Sante Fe: School of American Research Press.

French, H. (1991, April 14). To Suriname refugees, truce means betrayal. The New York Times.

Green, S. (2012). A sense of border. In T. Wilson \& H. Donnan (Eds.). A companion to border studies (pp. 573-592). Oxford: Wiley-Blackwell.

Green, S. (2013). Borders and the relocation of Europe. Annual Review of Anthropology, 42, 345-361.

Grenier, G.-M. (2011). Guyane-Amapá: Mieux structurer les territoires pour intensifier les échanges. Cayenne: CEROM.

Grotti, V. (2013). The wealth of the body: Trade relations, objects, and personhood in northeastern Amazonia. Journal of Latin American and Caribbean Anthropology, 18(1), 14-30.

Harris, C. A. (Ed.). (1928). A relation of a voyage to Guiana by Robert Harcourt 1613: With Purcha's transcript of a report made at Harcourt's instance on the Marrawini district. London: Hakluyt Society.

Hemming, J. (1995). Red gold: The conquest of the Brazilian Indians. London: Papermac.

Hulme, P., \& Whitehead, N. (Eds.). (1992). Wild majesty: Encounters with Caribs from Columbus to the present day. An Anthology. Oxford: Clarendon Press.

Jolivet, A., E. Cadot, E. Carde, S. Florence, S. Lesieur, J. Lebas, \& P. Chauvin (2011). Migrations et soins en Guyane. Agence Française pour le Développement, 105, $1-118$.

Jolivet, A., Lebas, J. \& Chauvin, P. (2010). Migration, health, and care in French Overseas Territories. The Lancet, 376, 1827-1828.

Jolivet, M.-J. (2007). Approche anthropologique du multiculturalisme guyanais: 
Marrons et créoles dans l'Ouest. In I. Léglise (Ed.), Pratiques et représentations linguistiques en Guyane: Regards croisés (pp. 87-106). Paris: IRD Éditions.

Jolivet, M.-J. (2008). Histoires du marronnage ou le difficile renoncement des Ndjuka. In G. Collomb, \& M.-J. Jolivet (Eds.), Histoires, identités et logiques ethniques: Amérindiens, Créoles et Noirs Marrons en Guyane (pp. 77-106). Paris: Éditions du comité des travaux historiques et scientifiques.

Kambel, E.-R., \& MacKay, F. (1999). The rights of indigenous peoples and Maroons in Suriname. Copenhagen: IWGIA.

Kruijt, D., \& Hoogbergen, W. (2005). Peaceful relations in a stateless region: The post-war Maroni River borders in the Guianas. Tijdschrift voor Economische En Sociale Geografie 96(2), 199-208.

Martres, J.-P., \& Larrieu, J. (1993). Coutumes et droit en Guyane. Paris: Economica.

Ministère de la Défense. (2013). Guyane: pas de trêve de fin d'année pour l'opération Harpie. Retreived from http://www.defense.gouv.fr/actualites/articles/ guyane-pas-de-treve-de-fin-d-annee-pour-l-operation-harpie

PAHO (2012). Suriname. Retrieved from http://www.paho.org/hq/index.php? option=com_docman\&task=doc_view\&gid=25194\&Itemid=

PAHO/WHO. (2012). Health in the Americas: Regional overview and country profiles. Retrieved from http://www.paho.org/saludenlasamericas/index.php? option=com_content\&view=article\&id=9\&Itemid=14\&lang=en

Parc. (2013). Qu'est-ce que le Parc amazonien de Guyane? Le plus grand parc national de France et de l'Union européenne. Retrieved from http://www .parc-amazonien-guyane.fr/le-parc-amazonien-de-guyane/carte-identite/

Pedersen, M.A. \& Holbraad, M. (2013). Introduction: Times of security. In M. Holbraad, \& M.A. Pedersen (Eds.), Times of security: Ethnographies of fear, protest, and the future (pp. 1-27). London: Routledge.

Pina-Cabral, J. de. (1999). Trafic humain à Macao: les compatibilités équivoques de la communication interculturelle. Ethnologie Française, 29(2), 225-236.

Pratt, M.-L. (1991). Arts of the contact zone. Profession, 91, 33-40.

Price, R. (2002). Maroons in Suriname and Guyane: How many and where. Nieuwe West-Indische Gids 76(1/2), 81-88.

Price, R. (2011). Rainforest warriors: Human rights on trial. Philadelphia: University of Pennsylvania Press.

Price, R. (2012). Saramaka people v Suriname: A human rights victory and its messy aftermath. Cultural Survival. Retrieved from http://www.culturalsurvival.org/ news/saramaka-people-v-suriname-human-rights-victory-and-its-messy-af termath\#sthash.CNWinL6S.dpuf

Rohan, J. de, Dupont B., Berthou J., \& Antoinette, J.-E. (2011). La Guyane: une approche globale de la sécurité. Rapport d'information $n^{\circ} 271$ (2010-2011), fait au nom de la Commission des Affaires Étrangères et de la Défense, déposé le 1er février 2011.

Roselé, S. (2013). Harpie: Huit kilos d'or saisis et des opérations en baisse. FranceGuyane, 2013 février 2013. Retrieved from http://www.franceguyane.fr/regions/ guyane/harpie-huit-kilos-d-or-saisis-et-des-operations-en-baisse-153996.php

Sahlins, M. (1979). L'apothéose du capitaine Cook. In M. Izard \& P. Smith (Eds.), La fonction symbolique. Paris: Gallimard. 
Schmitt, C. (2007). Political theology: Four chapters on the concept of sovereignty. Chicago: University of Chicago Press.

Simonian, L.T.L., \& Da Silva Ferreira, R. (2006). Brazilian migrant workers in French Guiana. In R. Gowricharn (Ed.), Caribbean transnationalism: Migration, socialization, and social cohesion (pp. 99-116). Lanham: Lexington Books.

Theije, M. de. (2006). Transnationalism in Suriname: Brazilian migrants in Paramaribo. In R. Gowricharn (Ed.), Caribbean transnationalism: Migration, socialization, and social cohesion (pp. 117-136). Lanham: Lexington Books.

Theije, M. de, \& Bal, E. (2010). Flexible migrants: Brazilian gold miners and their quest for human security in Surinam. In T. H. Eriksen, E. Bal, \& O. Salemink (Eds.), A world of insecurity: Anthropological perspectives on human security (pp. 66-85). London: Pluto Press.

Theije, M. de, \& Heemskerk, M. (2010). Transforming land tenure systems in the quest for gold: Aluku, Wayana, and the state in the Suriname French Guiana border region. In E. Barone-Visigalli, A. Roosevelt, \& G. Police (Eds.), Amaz'hommes: Sciences de l'homme et sciences de la nature en Amazonie (pp. 353365). Cayenne: Ibis Rouge.

Thoden van Velzen, H., \& Hoogbergen, W. (2011). Een zwarte vrijstaat in Suriname. De Okaanse samenleving in de 18e eeuw. Leiden: KITLV.

UNHCHR. (2010). Committee on the elimination of racial discrimination. France: Concluding observations. Geneva: Office of the United Nations High Commissioner for Human Rights, 77th session, 2010, report CERD/C/FRA/CO/17-19.

UNOCHA. (n.d.). Human security approach. United Nations Office for the Coordination of Humanitarian Affairs/ United Nations Trust Fund for Human Security. Retrieved from http://www.unocha.org/humansecurity/ human-security-unit/human-security-approach

van Wetering, W., \& Thoden van Velzen, H. (2013). Een zwarte vrijstaat in Suriname. De Okaanse samenleving in de 19 e en 20 e eeuw. Leiden: E.J. Brill.

Weisberg, C. (2013). "The children are our wealth": Maternity and national identity in French Guiana. Unpublished bachelor's dissertation, Princeton University.

Wesley Scott, J. (2012). European politics of borders, border symbolism and cross-border cooperation. In T. Wilson \& H. Donnan (Eds.). A companion to border studies (pp. 83-99). Oxford: Wiley-Blackwell.

Williamson, J. (1923). English colonies in Guiana and on the Amazon 1604-1668. Oxford: Clarendon Press.

Wilson, T., \& Donnan, H. (2012). Borders and border studies. In T. Wilson \& H. Donnan (Eds.), A companion to border studies (pp. 1-26). Oxford: Wiley-Blackwell.

\section{Sécurisation, altérité et l'Etat: (in) sécurité humaine dans une zone frontalière amazonienne}

\section{Marc Brightman et Vanessa Grotti}

Résumé : En se concentrant sur la région entourant le fleuve Maroni, qui forme la frontière entre le Suriname et la Guyane française, nous exami- 
nons comment les relations entre les différents groupes sociaux étatiques et non-étatiques sont articulées en termes de sécurité. La région est caractérisée par de multiples «frontières» et les frontières de toutes sortes, la frontière de l'État ayant les caractéristiques d'une interface ou zone de contact. De nombreuses et importantes collectivités se rencontrent dans cette zone frontalière: Indigènes d'Amazonie, la communauté tribale Maroon, les migrants brésiliens à la recherche de l'or et les fonctionnaires d'Etat de la France métropolitaine. Nous explorons les relations entre ces différents groupes d'acteurs, et décrivons la manière dont leurs rencontres mutuelles sont centrées sur les discours relatifs à la sécurité humaine et l'État, remettant ainsi en cause l'idée communément admise de la région en tant zone apatride et montrant par la même que la «sécurité humaine» des citoyens perçue du point de vue de l'État peut rivaliser avec des idées saillantes au niveau local ou des expériences relatives au bien-être.

Mots-clés: l'altérité, la frontière, la Guyane française, les mines d'or, la santé, la sécurité humaine, les peuples indigènes et tribaux, la sécurisation, le Suriname

\section{La "Seguritización", la alteridad y el Estado: la (in)seguridad humana en una frontera Amazónica}

\section{Marc Brightman y Vanessa Grotti}

Resumen: El artículo examina cómo se articulan las relaciones en términos de seguridad entre grupos estatales y no estatales en la región que rodea el Río Maroni (frontera entre la Guyana francesa y Surinam). La región se caracteriza por múltiples "límites" y tipos de fronteras, teniendo así la frontera Estatal características de una zona de contacto o de una interfaz. Importantes comunidades se encuentran en esta zona de frontera: Nativos del Amazonas, comunidades tribales del Maroni, buscadores de oro brasileños y funcionarios estatales franceses. Los autores exploran las relaciones entre estas diferentes redes de actores, y describen la manera en que sus mutuos encuentros se centran en discursos de seguridad humana y del Estado, desafiando así, el tradicional enfoque que sostiene la región como una zona sin Estado y mostrando que la "seguridad humana" desde la perspectiva del Estado puede competir con importantes ideas locales o con experiencias de bienestar.

Palabras claves: alteridad, cuidado de la salud, extracción de oro, frontera, indígenas y tribus, seguridad humana, seguritización 